\title{
Extended spawning in brown trout (Salmo trutta) populations from the Southern Iberian Peninsula: the role of climate variability
}

\author{
José E. LARIOS-LÓPEZ,,$^{*}$ José M. TIERNO DE FIGUEROA, ${ }^{1}$ Miguel GALIANA-GARCÍA, ${ }^{2}$ Javier GORTÁZAR, ${ }^{3}$ \\ Carlos $\mathrm{ALONSO}^{4}$
}

\begin{abstract}
${ }^{1}$ Departamento de Zoología, Facultad de Ciencias, Universidad de Granada, Campus Fuentenueva s/n, 18071 Granada; ${ }^{2}$ Agencia de Medio Ambiente y Agua de Andalucía, Avda. Joaquina Eguaras 10, Bajos del Edificio Victoria, 18013 Granada; ${ }^{3}$ Ecohidráulica, S.L., Calle Rodríguez San Pedro 2, Of. 807, 28015 Madrid; ${ }^{4}$ ETS Ingenieros de Montes, Universidad Politécnica de Madrid, Ciudad Universitaria s/n, 28040 Madrid, Spain

*Corresponding author: larios@correo.ugr.es
\end{abstract}

\begin{abstract}
The reproductive periods of brown trout (Salmo trutta) populations in 12 rivers in the Baetic Mountains in southern Spain were studied from 2008 to 2013. This area is an ecological and geographical limit for the distribution of this species in Europe. We found that the spawning period has been markedly extended in these fish. The mean spawning dates in the studied populations are consistent with the European trend at this latitude, but our data suggest that females from most of the populations that we studied are able to produce eggs from early October through late April or early May, yielding a reproductive period of between 150 and 170 days, the longest and most delayed brown trout reproduction periods that have been reported in the literature. We believe that such expanded spawning periods result primarily from the unpredictability of the Mediterranean climate, although it is possible that other factors may have contributed to the development of this reproductive behaviour. This hypothesis is discussed in the context of a comparison of our results with those found for other European S. trutta populations.
\end{abstract}

Key words: Salmonids, reproduction, plasticity, Mediterranean climate, rainfall, unpredictability, temperature.

Received: September 2014. Accepted: December 2014.

\section{INTRODUCTION}

The brown trout (Salmo trutta L.) is a Palaearctic species that exhibits high genetic, ecological and morphological variability (Bernatchez et al., 1992; Klemetsen et al., 2003) within its native area, which extends from Norway and Rus$\operatorname{sia}\left(71^{\circ} \mathrm{N}\right)$ in the north to the Atlas Mountains $\left(30^{\circ} \mathrm{N}\right)$ in the south (Jonsson and Jonsson, 2011; Snoj et al., 2011).

The Baetic Mountains (latitude $36^{\circ}-38^{\circ} \mathrm{N}$ ) in the Iberian Peninsula are the south western boundary of this species' habitat in Europe and thus represent an ecological limit for the distribution of $S$. trutta. In this area there is great topographical diversity with elevations ranging from 0 to $3482 \mathrm{~m}$ asl; this diversity permits the presence of rivers with rainfall, snowmelt and rain-on-snow hydrological regimes. Moreover, this region has a Mediterranean climate, with a cool, wet season followed by a warm, dry season; this climate pattern causes a sequence of often extreme floods and droughts (Gasith and Resh, 1999; Tierno de Figueroa et al., 2013).

Over the past century, brown trout have experienced range contraction and displacement toward higher elevations in these mountains (Menor and Prenda, 2006; Sáez, 2010). Currently, the species is distributed in isolated resident populations that generally occupy small areas. The connectivity among these populations appears to have never been very strong, but anthropogenic factors have reduced connectivity among these populations further. Almodóvar et al. (2010) showed that these populations are genetically distinct and possess haplotypes that have not been described previously.

In habitats at the limit of the ecological niche for a given species, environmental pressures driving selection may be stronger and hence of greater adaptive significance for this species (Lesica and Allendorf, 1995; Antunes et al., 2006). Thus, Iberian rivers could have acted as a refuge for $S$. trutta during the last ice age of the Quaternary (GarcíaMarín et al., 1999; Sanz et al., 2000; Suárez et al., 2001), allowing uninterrupted speciation processes to occur for a longer period in this region than elsewhere in the native area of this species. In this way, the high phenotypic and ecological plasticity of this species (Elliot, 1994; Ayllón et al., 2010; Valiente et al., 2010), together with the specific characteristics of the distribution of $S$. trutta populations and of the topography and climate of this region, could have allowed the appearance of particular adaptive traits, such as those reported in Cyprinidae (Carmona et al., 1997) or aquatic invertebrates (Giller and Malmqvist, 1998) inhabiting similar environments.

Along its wide geographical native range, S. trutta exhibits a continuum of life history tactics (Cucherousset et al., 2005) that range from anadromy to residence. The re- 
productive traits of S. trutta are likely to exhibit a similarly wide range of variation. For example, significant latitudinal variations in the mean spawning date and in the duration of the spawning period have been observed. The effects of latitude on brown trout spawning have been shown to be related to water temperatures (Elliott, 1982; Jonsson and L'Abée-Lund, 1993; Ojanguren and Braña, 2003); lower water temperatures require a longer incubation period (Crisp 1988; Elliott and Hurley, 1998; Klemetsen et al., 2003). Consequently, a cline in spawning periods is observed: spawning occurs from October through December in northern Europe and from January through March in more southern populations. Thus, in general, it has been assumed that $S$. trutta spawning periods rarely last for more than 1 or 2 months. On the other hand, this widespread reproductive behaviour, which is influenced by latitude, may also vary due to specific genetic or environmental factors. Thus, a population of sea trout (S. trutta, anadromous form) in a stream in Denmark spawned from October to February in the same breeding season (Aarestrup and Jepsen, 1998). However, examples of variation in the cline in spawning time are more frequently observed in populations inhabiting the southernmost boundary of this species' habitat. In the Metauro River in Italy $\left(43^{\circ} \mathrm{N}\right)$, Caputo et al. (2010) observed early spawning (November-January) typical in populations at northern latitudes. These authors linked this anomaly in the latitudinal cline to genetic introgression because the population had been highly stocked with Atlantic strains since at least the beginning of the $20^{\text {th }}$ century. At more southern latitudes, Gortázar et al. (2007) observed longer spawning periods (from December to April) to occur in populations in the Castril River in Spain $\left(37^{\circ} \mathrm{N}\right)$. These authors hypothesized that this phenomenon may be a response to catastrophic events (floods and droughts) in populations connected to a reservoir.

The present study had three aims: i) to describe regional and local patterns of the reproductive phenology of S. trutta populations from the Baetic Mountains; ii) to compare spawning data among populations inhabiting different rivers in the study area and between the study area and other European areas; and iii) to discuss the effects of climatic variability or other possible factors on spawning dates and durations. The conclusions of this work will increase our knowledge of the local adaptations to climatic drivers of life history traits.

\section{Study area}

The study populations inhabit the upper reaches of several rivers originating in the Baetic Mountains. These rivers belong to three basins: the Guadalquivir, South Mediterranean and Segura river basins (Fig. 1). The sampling sites that were studied are located between the coordinates $38^{\circ} 03^{\prime}-36^{\circ} 30^{\prime} \mathrm{N}$ and $03^{\circ} 51^{\prime}-02^{\circ} 45^{\prime} \mathrm{W}$.

Twelve populations were studied. These populations were distributed in three different mountain systems: the Sierra de Alhama - Tejeda - Almijara in the west, the Sierra Nevada in the southeast and the Sierras de Cazorla - Segura - Las Villas y Castril in the north (Fig. 1). All of the populations studied are resident populations that are completely isolated and exhibit no connectivity within the same mountain system. The sampling locations were at very diverse elevations, particularly in Sierra Nevada (Tab. 1).

\section{METHODS}

Female salmonids lay their eggs in pits that they dig in gravel beds, and the series of nests that are usually placed in a row by a female is known as redd (Jonsson and Jonsson, 2011). Redd counts are accepted as an effective, economical and non-invasive method for identifying spawning periods (Dunham et al., 2001). However, this method was not used in this study because the sampling sites were at high elevations and were difficult to access because of the rugged terrain; the widths of the sampling sites typically did not exceed 3 metres, and dense forests were present on the riverbanks. In addition, due to the high slope and low order of the rivers that were studied (primarily orders 1 and 2), a large number of large rocks were frequently found in the riverbed. Thus, the hydrogeomorphology of the rivers examined in this study is characterised by frequent rapids that produce turbulent water surfaces and by pools that prevent the formation of large spawning areas. It is also known (AlChokhachy and Budy, 2005) that difficulties in detecting redds constructed by small resident fish may prevent accurate monitoring of a reproductive population. In previous demographic studies (Supplementary Material), we showed that adults in the trout populations analysed in this study did were not usually more than 3 years old $(3+)$ and were primarily $2+$ females (usually $18-25 \mathrm{~cm} \mathrm{Lf}$ ), which cannot displace a considerable amount of substrate during redd construction. Hence, in these rivers, counting redds is not the recommended method for identifying spawning periods; thus, electrofishing and stripping are allowed. These methods generate the most consistent results in the study area.

Between one and three sampling sites in each of the twelve selected rivers were chosen (Tab. 1). For six consecutive sampling periods (from 2008 to 2013), surveys were conducted using single-pass electrofishing between September and June. Each spawning period includes the autumn of the previous year and the winter and spring of the indicated year (e.g., the 2008 spawning period includes the period from autumn 2007 to spring 2008).

During the first two years of the study period, surveys were conducted monthly to determine when spawning periods occurred in general. In the final years of the study, the sites were sampled every two weeks, at the beginning and the end of the spawning period, to refine our knowledge of the start and end of the reproductive period in each river. Thus, when females with mature eggs were detected for the 
first time each year, we did not sample again until the beginning of the following spring. In the spring, surveys were conducted every two weeks until either all females that were examined had spawned, no females were forming eggs or no females with mature eggs were observed.

Because of our previous analyses of individual growth in the study region, we were able to estimate the ages of trout by their body size (fork length, henceforth $\mathrm{L}_{\mathrm{f}}$; Supplementary Material). In each survey, we collected a minimum of 30 adult trout ( 2 or more years old). The length of every individual was measured (to the nearest $1 \mathrm{~mm}$ ), every individual was weighed (to the nearest $0.01 \mathrm{~g}$ ), and the status of each individual's gonads was evaluated after gently stripping them. When a mature individual was detected, only a small quantity of gametes was extracted to identify the sex of the individual. Because males produce sperm longer than females produce eggs, only females were used to define active spawning periods. The maturation status of every female was examined, and all of the females were classified into three categories: females forming eggs, females with mature eggs and recently spawned females (females with loose abdomens). After data collection, all specimens were returned to the same reach of the sampling site.

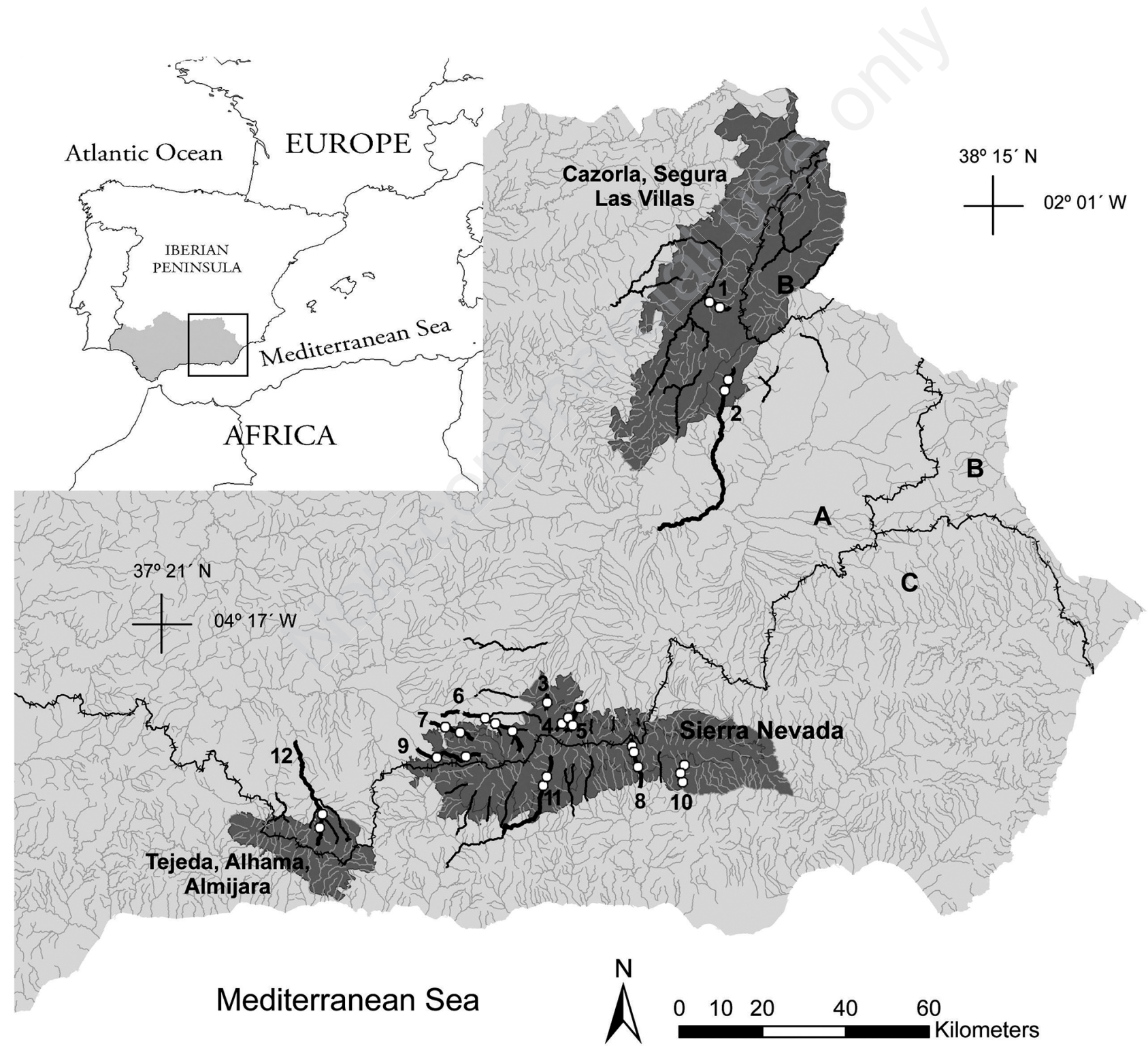

Fig. 1. Location of the study area. Basins delimited: Guadalquivir (A), Segura (B) and South Mediterranean (C). Fluvial network (gray lines), rivers inhabited by Salmo trutta (thin and thick black lines), the rivers that were studied (thick black lines) and sampling sites are also shown. The river numbers shown in this figure match those listed in Tab. 1. 
A population was considered to be spawning when females with mature eggs or both females maturing eggs and spawned females were detected in the same survey. A confirmed spawning period (grey bar in Fig. 2) for a particular river was determined by aggregating all of the dates on which spawning trout were observed in all of the studied years. There were sometimes obvious evidences that a spawning period may have been longer than the confirmed spawning period. Thus, we defined a probable spawning period (white bar in Fig. 2) based on the occurrence of any of the following: i) females with mature eggs were detected in the first survey in the confirmed period; this implies that spawning very likely occurred in the days before the survey; ii) females with mature eggs were detected in the last survey in the confirmed period; this implies that spawning females were present in the days after the survey; and iii) females in a survey conducted after the confirmed period had obvious signs of having recently spawned; these females must have spawned in the days before the survey. The total spawning period was defined as the sum of confirmed spawning period and the probable spawning period. In addition, the confirmed spawning duration (the number of days in a confirmed spawning period), total spawning duration (the number of days in a total spawning period) and the mean spawning date (within the total spawning period) were calculated for each river (Tab. 1). The mean spawning date was used to determine (by means of simple regression analysis using STATISTICA software version 8.0; StatSoft, Tulsa, OK, USA) whether our results for the southernmost brown trout populations in Europe agreed with the latitudinal trend in spawning dates observed in northern populations (Klemetsen et al., 2003). Mean spawning dates calculated in this study were compared with mean spawning dates reported in the literature, as reviewed by Gortázar et al. (2007), to achieve this goal.

In addition, the rainfall regime during the period 19802009 was calculated for 4 rivers in the study area $(1,6,10$ and 12 shown in Fig. 1 and Tab. 1) to observe the natural variability in flow regimes. The estimates given were calculated for the reaches inhabited by S. trutta in these rivers and their tributaries. The Watershed function of Spatial Analyst extension of ArcGIS 9.3.1. software (ESRI 2009) was used to set the boundaries of the watersheds of the inhabited reaches. Monthly rainfall in each watershed was determined using the Zonal statistics as table function of the Spatial Analyst extension. Monthly rainfall date were obtained from the REDIAM (Environmental Information Network of Andalusian Government). Finally, with the aim of including all data in a simpler graph, seasonal rainfall was calculated for each year, based on the average litres per square metre that were measured in winter (January+February+March), spring (April+May+June), summer (July+August+September) and autumn (October+November+December; Fig. 3).

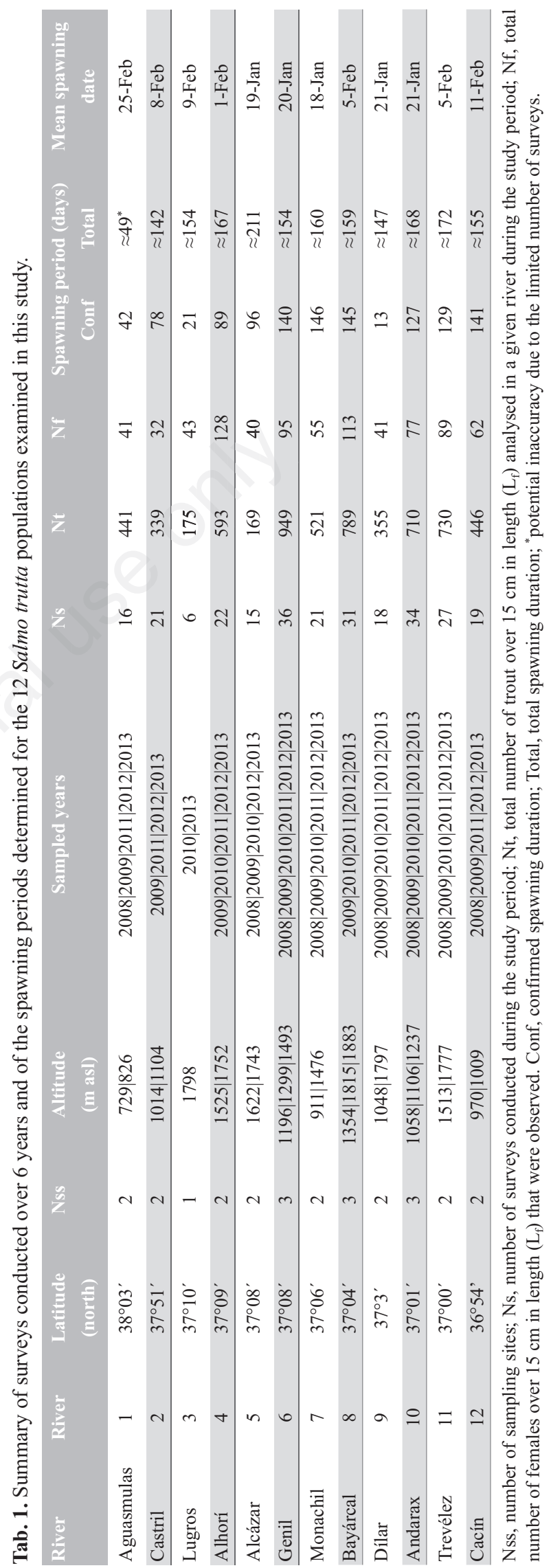




\section{RESULTS}

Date were obtained for 26 sampling points in 12 rivers belonging to two different river basins (Guadalquivir, rivers 1, 2, 3, 4, 5, 6, 7, 9 and 12; and South Mediterranean, rivers 8, 10 and 11; Fig. 1) and analysed. During the sampling period, which was distributed in six campaigns from 2008 through 2013, 266 surveys were conducted, 6217 S. trutta were stripped and 816 of them were sexed as females (Tab. 1).

The lengths of the spawning seasons in the studied rivers were determined (Tab. 1). The longest confirmed spawning period lasted 211 days (in the Alhorí River), and all of the probable spawning periods lasted longer than 142 days (except in the Aguasmulas River, most likely due to the limited number of surveys conducted in this river). The data obtained in this study suggest that the sets of females present in some of the rivers that were studied can produce eggs from early October through late April or early May, for a period of between 150 and 170 days (i.e., between 5 and nearly 6 months). The period in which males produced sperm was even more extended, but this period was not considered here because females define the spawning periods (see the Methods section).

The mean spawning dates in all of the studied rivers agreed with European latitudinal trends [Fig. 4; $y=-4.04$. $\mathrm{x}+267.76 ; \mathrm{R}^{2}$ adjusted $=0.755, \mathrm{P}<0.05$; residuals of the fitted model satisfies the assumptions of normality and homoscedasticity; as dependent variable we used the mean spawning date in days since September 30, which is the first date of mean spawning in Europe compiled by Gortázar et al. (2007)]. Rainfall regime in the study area exhibited high interannual variability (Fig. 3), as expected in a Mediterranean-climate zone.

\section{DISCUSSION}

S. trutta is known to exhibit high phenotypic plasticity throughout its extensive area of distribution (Elliot, 1994; Ayllón et al., 2010; Valiente et al., 2010). At the same time, the reproductive rhythms in salmonids have a strong genetic basis, as a consequence of adaptation to particular environmental conditions in geographic isolation (Northcote, 1992; Elliott, 1994). This fact may be particularly relevant for the populations inhabiting the study area, which have been isolated since the last glacial retreat (ca. 13,000 years ago). Several factors could have acted separately or together to affect the development of the reproductive behaviour observed in the trout populations that were studied (Tab. 1, Fig. 2). Considering the geographical location of the studied populations (Fig. 1), we believe that such prolonged spawning periods (extended spawning) are primarily conditioned by characteristics of the Mediterranean climate, particularly rainfall variability. These and other possible factors are discussed below.

Temperature is an important parameter in the life cycle (Gillooly et al., 2001). Several aspects of ontogenetic development and reproductive success in salmonids are gov-

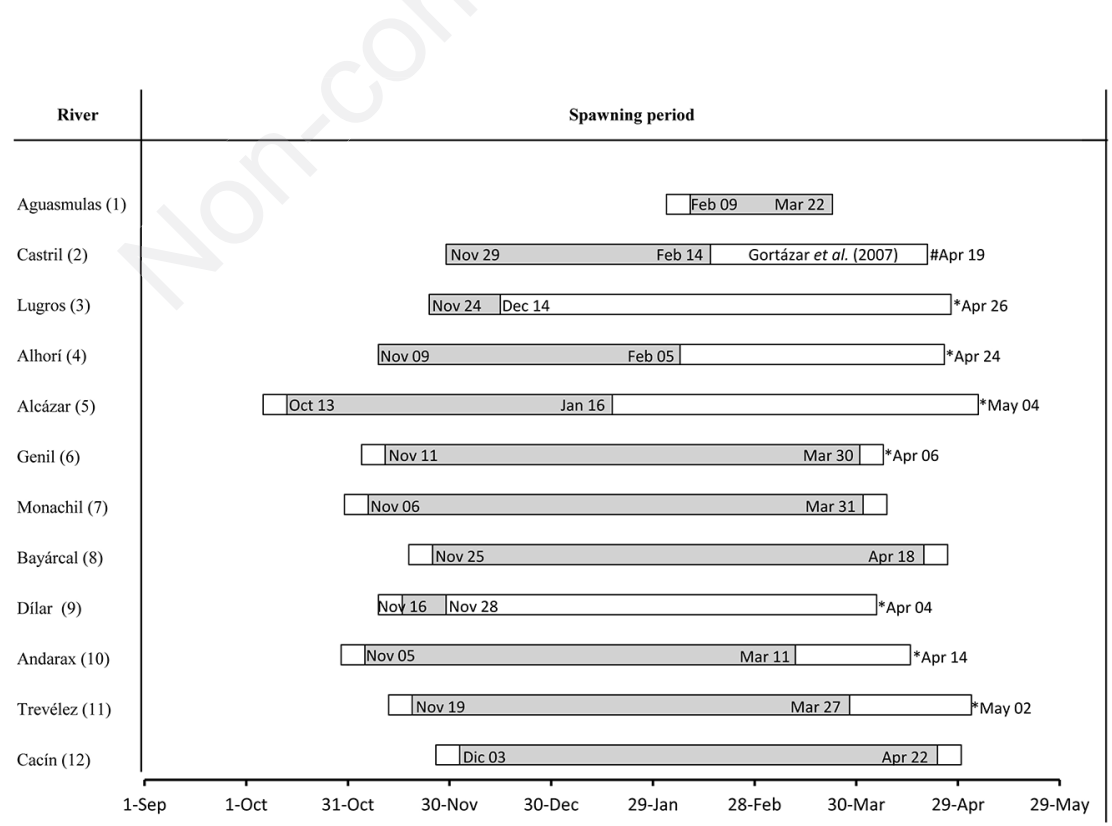

Fig. 2. Spawning periods. Grey bars indicate confirmed spawning periods. White bars indicate probable spawning periods. The dates indicate the first and last dates on which females with mature eggs were observed in a given river. The dates marked with an asterisk indicate that all females surveyed on that date exhibited obvious signs of having recently spawned. In the Castril River, the last redd observed by Gortázar et al. (2007) is indicated as \#date. The river numbers shown in this figure match those listed in Tab. 1. 
erned by temperature-dependent processes: the number and sizes of eggs, the duration of embryonic development, the duration of the hatching periods, survival rates before and after hatching and fry emergence (Ojanguren and Braña, 2003; Lobón-Cerviá and Mortensen, 2005; Lahnsteiner and Leitner, 2013). Similarly, the duration of the incubation period and the duration of endogenous larval feeding are temperature-dependent: the lower the temperature, the longer the duration. Moreover, several investigators have found that the start date of spawning exhibits a latitudinal trend; the start date is delayed in southern populations compared with northern populations (Jonsson and L'Abée-Lund, 1993; Klemetsen et al., 2003; Gortázar et al., 2007).

In addition to latitude, elevation is another factor capable of modulating the water temperature as it can mimic the effect of latitude on temperatures. In fact, it is often assumed that elevation gradients can be used as a proxy for understanding ecological processes along latitudinal gradients (Hansen et al., 1997; Körner, 2007; Halbritter et al., 2013). Given the modulating effects of latitude and elevation on water temperatures, the spawning periods of S. trutta populations located in high mountain systems at lower latitudes could be similar to those of populations inhabiting lower elevations at higher latitudes. Gortázar et al. (2007) thus investigated the relationship between latitude and elevation in the spawning date of European S. trutta populations. However, these investigators failed to find any significant effect of elevation using data extracted from previous publications, and this relationship thus had to be removed from the model. In fact, little is known about habitat conditions at spawning sites in rivers at higher elevations (Riedl and Peter, 2013).

The mean spawning dates in the populations examined in this study (Tab. 1) are in agreement with the latitudinal trend in mean spawning dates (Fig. 4) (Gortázar et al., 2007; Klemetsen et al., 2003). Nevertheless, the lengths of the spawning period of S. trutta populations located in the study area are considerably longer than any other reported spawning periods. Gortázar et al. (2007) reviewed the durations of spawning periods in different European brown trout populations and reported that no spawning period lasted longer than 100 days. By contrast, several populations in our study started their reproductive periods in October, and their reproductive periods extended to late April or early May (Fig. 2).

Variation in the reproductive periods among the populations in the rivers that were studied may be due to differences in temperature and hydrological regimes (rain-on-snow and snowmelt). Thus, all of the S. trutta populations studied in the Sierra Nevada (rivers 3, 4, 5, 6, 7, 8, 9, 10 and 11 in Fig. 1), which populations inhabit rivers originating in the highest elevations of the Iberian Peninsula (above $3000 \mathrm{~m}$ asl) and are greatly influenced by snow (snowmelt and rain-on-snow regimes), begin spawning early (Fig. 2). Other populations that inhabit
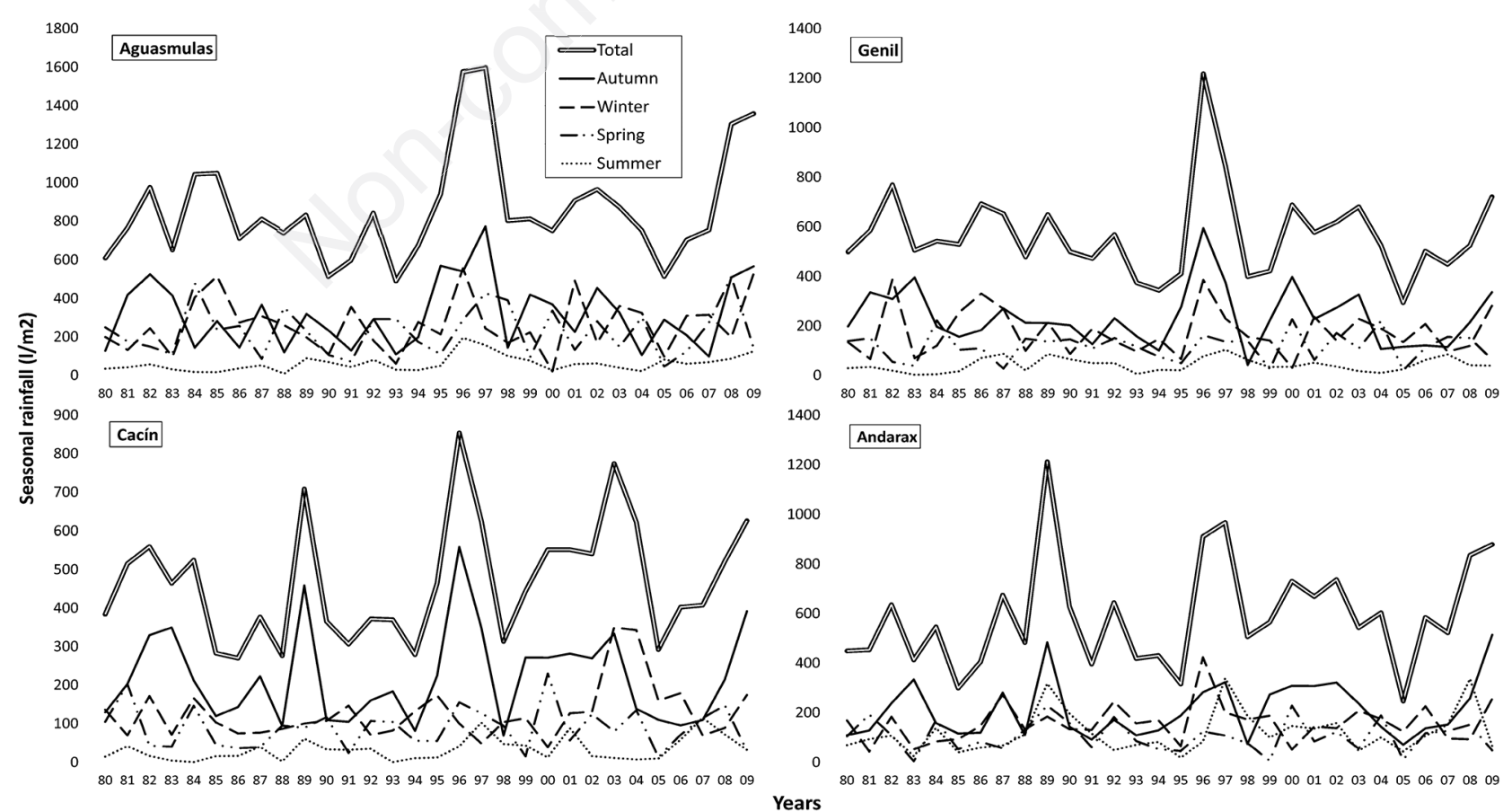

Fig. 3. Time series data for accumulated rainfall by season for three decades (1980-2009) for the Aguasmulas, Genil, Andarax and Cacín Rivers (1, 6, 10 and 12 in Fig. 1), showing the lack of interannual predictability of precipitation in the study area. 
rivers originating in lower-elevation mountain systems that are less influenced by snow (rain-on-snow and main rainfall regimes; e.g., the Cacín River and the Castril River, rivers 12 and 2 in Fig. 1, respectively) exhibit a slightly delayed spawning start relative to the populations of the Sierra Nevada (Fig. 2). On the other hand, in the Aguasmulas River (river 1 in Fig. 1), which is a typical mid-mountain Mediterranean river that is little influenced by snow (i.e., in a rainfall regime) and runs at lower elevations, water temperatures fluctuate more than in the other rivers studied, and the spawning period appears to start later than in the other rivers studied. Nevertheless, the relative lack of surveys in this river may have affected these findings (Fig. 2). Thus, the results of this study suggest that higher elevations, greater snowfall amounts, and consequently lower temperatures could affect the beginning of spawning periods at local scales.

Furthermore, the Mediterranean climate is widely recognised to be unpredictable (Gasith and Resh, 1999; Tierno de Figueroa et al., 2013). This unpredictability, which is related to the seasonality of the Mediterranean climate, directly affects water flows and causes periods of drought and flooding that can occasionally be extreme (Fig. 3). In summer, the flows in the rivers examined in this study decrease, and the water temperatures increase. Because S. trutta populations in the study area permanently inhabit high-middle reaches of rivers, drought periods seldom become extreme, and the water temperature threshold for the survival of the species (Jonsson and Jonsson, 2011) is rarely reached. Nevertheless, extreme flow decreases in the lower-elevation limits of the species distribution are sometimes observed, and such decreases can directly cause population disappearance in these locations (personal observations).

Likewise, increases in flow also greatly influence river communities in the studied reaches. For example, torren-

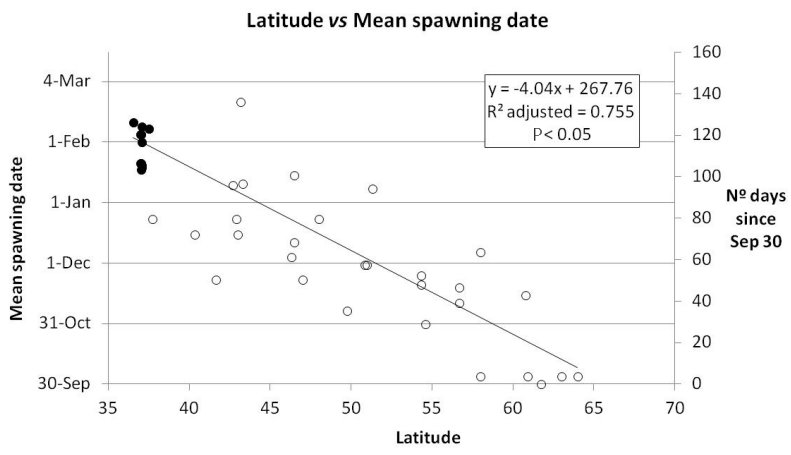

Fig. 4. Simple regression analysis examining the relationship between latitude and mean spawning date. Solid circles represent data collected in this study. Open circles represent previously published data (in Gortázar et al., 2007). tial spring rains can produce devastating effects in Mediterranean river ecosystems by altering the morphological structure of rivers and dragging plant and animal communities downstream (Gasith and Resh, 1999). In the study area increases in flows during winter and spring can be gradual or torrential, and the flows can increase repeatedly. Repeatedly increased flows are much more harmful to S. trutta populations (Jensen and Johnsen, 1999) because a high intensity of floods during the incubation and emergence periods may limit recruitment (Cattaneo et al., 2002; Lobón-Cerviá and Rincón, 2004; Unfer et al., 2011). Thus, mechanisms to avoid the detrimental effect of either or both drought and floods, which are stochastic events, could potentially be selectable features of species that inhabit unpredictable ecosystems. Aquatic insects, for example, exhibit important adaptations to unpredictable flow regimes (Giller and Malmqvist, 1998); egg diapause and delayed hatching are adaptations used by mayfly and stonefly species in temporary and desert streams, and some of these species may extend their hatching for up to 5-7 months (Dieterich and Anderson, 1995; Jacobi and Cary, 1996). Plasticity in life history allows the eggs of these species to remain in the substrate during summer droughts, so that development can be resumed when water flows again. Since trout have not developed these ecological adaptations, extended spawning may be an adaptive strategy with similar purposes.

Fig. 2 shows that females in the studied populations mature their eggs asynchronously, so that the reproductive period is able to last from five to more than six months. In other Mediterranean trout populations with extended spawning periods (Gibertini et al., 1990; Gortázar et al., 2007; Caputo et al., 2010), the spawning intensity (understood as the number of females spawning at a given time) is not constant throughout the reproductive period but does exhibit a temporal peak in intensity. It is known that spawning times have evolved to match offspring emergence with optimal seasonal environmental conditions (Heggberget, 1988; Jonsson and Jonsson, 2011). However, the presence of actively reproducing individuals before and after the spawning peak increases the chances of reproductive success for populations inhabiting rivers with interannually variable environmental conditions. Thus, individuals within the same populations may exhibit differences in the timing of reproductive behaviours. With such variability in the reproductive strategies of a given population, the longer the spawning period, the greater the capacity of the population to avoid negative consequences of stochastic phenomena. Thus, the ecological advantages provided by extended spawning in the context of the unpredictability of the Mediterranean climate may have allowed the $S$. trutta populations that inhabit the study area to develop the largest known reproductive periods of any trout population. 
In general, freshwater fishes exhibit prolonged spawning periods in tropical and subtropical regions, while this strategy is uncommon in temperate areas (Nikolsky, 1963; Jonsson and Jonsson, 1993). Thus, the extended spawning period observed in this study is not an expected reproductive mechanism in freshwater fishes inhabiting European latitudes. Nevertheless, longer-than-expected spawning periods have been observed in fish populations inhabiting environments with uniform water temperatures and food supplies available throughout the year (Sigler and Sigler, 1990), but these conditions are far from those observed in our study. A small number of Salmonid populations with longer spawning periods have been observed previously; the longer spawning periods in these populations have been thought to be related to the presence of a reservoir (Gortázar et al., 2007), to heavy introgression with Atlantic haplotypes (Caputo et al., 2010), or to altered photoperiods (Zerunian et al., 1996). However, in our study area, most populations inhabit river sections that are not connected with reservoirs, the annual effect of the photoperiod is not altered and the percentage of genetic introgression is extremely low or zero (Almodóvar et al., 2010). Moreover, it is known (Leggett and Carscadden, 1978) that the fine-tuning of reproductive strategies to local environmental conditions may be widespread among fish and may be the ultimate basis for the evolution of homing. Thus, migratory salmonids such as anadromous $S$. trutta populations or Atlantic salmon (Salmo salar L. 1758) exhibit a latitudinal cline in their spawning activities. However, the salmonid populations that have exhibited extended spawning in Southern Europe (S. fibreni in Lake Posta Fibreno and the $S$. trutta populations studied in this paper) are resident populations. It is likely that the disconnection of the life cycles of resident populations from phenomena associated with ocean dynamics and the need to have lower energy expenditures during migration (populations sometimes ascend only tens or hundreds of metres to spawn) has been an enabling factor in the development of the extended spawning periods that have been observed in resident populations.

\section{CONCLUSIONS}

The intra-populational asynchrony observed during the spawning period in the populations examined in this study could act as a reproductive mechanism that provides advantages within the framework of the unpredictability of the Mediterranean climate, which can cause stochastic events such as drought, floods or heavy rains that can affect the reproductive success of these populations. Furthermore, it is likely that the water temperature acts as a local modulating factor at the beginning of the breeding period and that local variations in water temperature could thus explain the differences observed among the populations in the mountain systems investigated in this study. We thus suggest that variations in water temperature (occurring as a re- sult of local interaction between latitude, elevation and hydrological regime), unpredictable climatic factors and the life history tactics (migratory versus resident forms) of a given population should be considered to be the main drivers of the reproductive periods of $S$. trutta.

\section{ACKNOWLEDGMENTS}

This study is framed in the projects Recuperación de las poblaciones de trucha común en Andalucia (1589/2007/M/00) and Seguimiento de los efectos del Cambio Global en Sierra Nevada: 2010-2014 (562/2010/M/00). The authors thank to the Environmental Council of the Andalusian Government and Sierra Nevada National Park for their managerial support, and Drs. López-Rodríguez, Giovanni B. Delmastro and Stefano Fenoglio for his valuable help.

\section{REFERENCES}

Aarestrup, K, Jepsen N, 1998. Spawning migration of sea trout (Salmo trutta (L)) in a Danish river. Hydrobiologia 371/372: 275-281.

Al-Chokhachy R, Budy P, 2005. Understanding the Significance of Redd Counts: a Comparison between Two Methods for Estimating the Abundance of and Monitoring Bull Trout Populations. North Am. J. Fish. Mana. 25:1505-1512.

Almodóvar A, Nicola GG, Leal S, Elvira B, 2010. [Análisis genético de las poblaciones de Trucha Común Salmo trutta en la Comunidad Autónoma de Andalucía].[Report in Spanish].Memoria Final Proyecto Egmasa-Junta de Andalucía y Universidad Complutense de Madrid. Environmental Council of the Andalusian Government, Sevilla, Spain.

Antunes A, Faria R, Johnson WE, Guyomard R, Alexandrino P, 2006. Life on the edge: the long-term persistence and contrasting spatial genetic structure of distinct brown trout life histories at their ecological limits. J. Hered. 97:193-205.

Ayllón D, Almodóvar A, Nicola GG, Elvira B, 2010. Ontogenetic and spatial variations in brown trout habitat selection. Ecol. Freshw. Fish 19:420-432.

Bernatchez L, Guyomard R, Bonhomme F, 1992. DNA sequence variation of the mitochondrial control region among geographically and morphologically remote European brown trout Salmo trutta populations. Mol. Ecol. 1:161-173.

Caputo V, Giovannotti M, Splendiani A, 2010. Pattern of gonad maturation in a highly stocked population of brown trout (Salmo trutta L., 1758) from Central Italy. Ital. J. Zool. 77:14-22.

Carmona JA, Sanjur OI, Doadrio I, Machordom A, Vrijenhoekt RC, 1997. Hybridogenetic Reproduction and Maternal Ancestry of Polyploid Iberian Fish: The Tropidophoxinellus alburnoides Complex. Genetics 146:983-993.

Cattaneo F, Lamouroux N, Breil P, Capra H, 2002. The influence of hydrological and biotic processes on brown trout (Salmo trutta) population dynamics. Can. J. Fish. Aquat. Sci. 59:12-22.

Crisp DT, 1988. Prediction from temperature of eyeing, hatching and 'swim up' times for salmonid embryos. Freshwater Biol. 19:41-48.

Cucherousset J, Ombredane D, Charles K, Marchand F, Baglinière JL, 2005. A continuum of life history tactics in a brown trout (Salmo trutta) population. Can. J. Fish. Aquat. Sci. 62:1600-1610. 
Dieterich M, Anderson NH, 1995. Life cycles and food habits of mayflies and stoneflies from temporary streams in western Oregon. Freshwater Biol. 34:47-60.

Dunham JB, Rieman BE, Davis K, 2001. Sources and magnitude of sampling error in redd counts for bull trout. North Am. J. Fish. Mana. 21:343-352.

Elliott JM, 1982. The effects of temperature and ration size on the growth and energetics of salmonids in captivity. Comp. Biochem. Physiol. Part B 73:81-91.

Elliott JM, 1994. Quantitative ecology and the brown trout. Oxford University Press: $286 \mathrm{pp}$.

Elliott JM, Hurley MA, 1998. An individual-based model for predicting the emergence period of sea-trout fry in a Lake District stream. J. Fish Biol. 53:414-433.

García-Marín JL, Utter FM, Pla C, 1999. Postglacial colonization of brown trout in Europe based on distribution of allozyme variants. Heredity 82:46-56.

Gasith A, Resh VH, 1999. Streams in Mediterranean climate regions: abiotic influences and biotic responses to predictable seasonal events. Annu. Rev. Ecol. Syst. 30:51-81.

Gibertini G, Ceccarelli E, Zerunian S, 1990. [Contributo alla conoscenza della riproduzione delle trote indigene nel lago di Posta Fibreno (Lazio) (Osteichthyes, Salmonidae)].[Article in Italian]. Riv. Idrobiol. 29:247-267.

Giller PS, Malmqvist B, 1998. The biology of streams and rivers. Oxford University Press: 296 pp.

Gillooly JF, Brown JH, West GB, Savage VM, Charnov EL, 2001. Effects of size and temperature on metabolic rate. Science 293:2248-2251.

Gortázar J, García de Jalón D, Alonso-González C, Vizcaíno P, Baeza Sanz D, Marchamalo M, 2007. Spawning period of a southern brown trout population in a highly unpredictable stream. Ecol. Freshw. Fish 16:515-527.

Halbritter AH, Alexander JM, Edwards PJ, Billeter R, 2013. How comparable are species distributions along elevational and latitudinal climate gradients? Global Ecol. Biogeogr. 22:1228-1237.

Hansen J, Sato M, Ruedy R, 1997. Radiative forcing and climate response. J. Geophys. Res. 102:6831-6864.

Heggberget TG, 1988. Timing of spawning in Norvegian Atlantic salmon (Salmo salar). Can. J. Fish. Aquat. Sci. 45:845-849.

Jacobi GZ, Cary SJ, 1996. Winter stoneflies (Plecoptera) in seasonal habitats in New Mexico, USA. J. N. Am. Benthol. Soc. 15:690-699.

Jensen AJ, Johnsen B, 1999. The functional relationship between peak spring floods and survival and growth of juvenile Atlantic salmon (Salmo salar) and brown trout (Salmo trutta). Funct. Ecol. 13:778-785.

Jonsson B, Jonsson N, 1993. Partial migration: niche shift versus sexual maturation in fishes. Rev. Fish Biol. Fisher. 3:348-365.

Jonsson B, Jonsson N, 2011. Ecology of Atlantic salmon and brown trout. Habitat as a template for life histories. Fish \& Fisheries Series 33. Springer, Dordrecht: 708 pp.

Jonsson B, L'Abée-Lund JH, 1993. Latitudinal clines in life-history variables of anadromous brown trout in Europe. J. Fish Biol. 43:1-16.

Klemetsen A, Amundsen PA, Dempson JB, Jonsson B, Jonsson N, O'Connell MF., Mortensen E, 2003. Atlantic salmon Salmo salar L., brown trout Salmo trutta L. and Arctic charr Salvelinus alpinus (L.): a review of aspects of their life histories. Ecol. Freshw. Fish 12:1-59.

Körner C, 2007. The use of "altitude" in ecological research. Trends Ecol. Evol. 22:569-574.

Lahnsteiner F, Leitner S, 2013. Effect of temperature on game- togenesis and gamete quality in brown trout, Salmo trutta. J. Exp. Zool. A Ecol. Genet. Physiol. 319:138-148.

Leggett WC, Carscadden JE, 1978. Latitudinal variation in reproductive characteristics of American shad (Alosa sapidissima): evidence for population specific life history strategies in fish. J. Fish. Res. Board Can. 35:1469-1478.

Lesica P, Allendorf FW, 1995. When are peripheral populations valuable for conservation? Conserv. Biol. 9:753-760.

Lobón-Cerviá J, Mortensen E, 2005. Population size in streamliving juveniles of lake-migratory brown trout Salmo trutta L.: the importance of stream discharge and temperature. Ecol. Freshw. Fish 14:394-401.

Lobón-Cerviá J, Rincón PA, 2004. Environmental determinants of recruitment and their influence on the population dynamics of stream-living brown trout Salmo trutta. Oikos 105:641-646.

Menor A, Prenda J, 2006. [Análisis histórico de las poblaciones de trucha (Salmo trutta Linnaeus, 1758) en Andalucía y Castilla la Mancha en el siglo XIX].[Article in Spanish]. Proceedings XIII Congreso de la Asociación Española de Limnología y V Congreso Ibérico de Limnología, Barcelona. Asociación Española de Limnología, Barcelona: 119 pp.

Nikolsky GV, 1963. The ecology of fishes. Academic Press, London: $352 \mathrm{pp}$.

Northcote TG, 1992. Migration and residency in stream salmonids - some ecological considerations and evolutionary consequences. Nord. J. Freshw. Res. 67:5-17.

Ojanguren AF, Braña F, 2003. Thermal dependence of embryonic growth and development in brown trout. J. Fish Biol. 62:580-590.

Riedl C, Peter A, 2013. Timing of brown trout spawning in Alpine rivers with special consideration of egg burial depth. Ecol. Freshw. Fish 22:384-397.

Sáez-Gómez P, 2010. [Análisis de la distribución histórica de la trucha común (Salmo trutta Linnaeus, 1758) en Andalucía. Datos preliminares].[Article in Spanish]. Ríos con vida 85:16-19.

Sanz N, Garcia-Marin JL, Pla C, 2000. Divergence of brown trout (Salmo trutta) within glacial refugia. Can. J. Fish. Aquat. Sci. 57:2201-2210.

Sigler WF, Sigler JW, 1990. Recreational fisheries: management, theory and application. University of Nevada Press, Reno: $418 \mathrm{pp}$.

Snoj A, Marić S, Bajec SS, Berrebi P, Janjani S, Schöffmann J, 2011. Phylogeographic structure and demographic patterns of brown trout in North-West Africa. Mol. Phylogenet. Evol. 61:203-211.

Suárez J, Bautista JM, Almodóvar A, Machordom A, 2001. Evolution of the mitochondrial control region in Palaearctic brown trout (Salmo trutta) populations: the biogeographical role of the Iberian Peninsula. Heredity 87:198-206.

Tierno de Figueroa JM, López-Rodríguez MJ, Fenoglio S, Sánchez-Castillo P, Fochetti R, 2013. Freshwater biodiversity in the rivers of the Mediterranean basin. Hydrobiologia 719:137-186.

Unfer G, Hauer C, Lautsch E, 2011. The influence of hydrology on the recruitment of brown trout in an Alpine river, the Ybbs River, Austria. Ecol. Freshw. Fish. 20:438-448.

Valiente AG, Juanes F, Nuñez P, Garcia-Vazquez E, 2010. Brown trout (Salmo trutta) invasiveness: plasticity in lifehistory is more important than genetic variability. Biol. Invasions 12:451-462.

Zerunian S, Lecce A, Gibertini G, 1996. Observations on the reproduction of Salmo fibreni (Osteichthyes, Salmonidae), p. 119-128. Proceedings V Nat. Congr. Associazione Italiana Ittiologi Acque Dolci, Montecchio Maggiore, Parma, Italy. 